BIOMEDICAL AND BIOSOCIAL ANTHROPOLOGY
$\begin{gathered}\text { Official Journal of the International Academy } \\ \text { of Integrative Anthropology } \\ \text { journal homepage: http://bba-journal.com }\end{gathered}$

\title{
Age and gender features of thigh rheogram indicators in practically healthy adolescents
}

Hmel L. L., Serebrennikova O. A., Kyrychenko Yu. V., Gnenna V. O.

National Pirogov Memorial Medical University, Vinnytsya, Ukraine

\section{ARTICLE INFO}

Received: 5 July, 2018

Accepted: 24 August, 2018

UDC: $616-071.2: 613.4: 611.9$ :

$613.956: 575.191$

CORRESPONDING AUTHOR

e-mail: liliako@i.ua Hmel L. L.

\begin{abstract}
According to many studies, the rheovasographic index of the thighs can detect slight changes in the vessels, do not constitute a critical inconvenience, but in advance indicate that more serious diseases of the lower limb are approaching. The purpose of the study is to determine the age and gender features of thigh rheogram indicators in practically healthy adolescents in the Podillia region of Ukraine. The rheographic parameters of the thighs of 103 practically healthy boys aged from 13 to 16 years old and 108 girls aged from 12 to 15 years, urban residents of the Podillia region of Ukraine, were determined using a cardiology computer diagnostic complex. The statistical processing of the obtained results was carried out in the license package "Statistica 5.5" using parametric and nonparametric methods for evaluating the obtained results. In 12-year-old girls, in comparison with other age groups, it was found that most of the amplitude indices (with the exception of the incisura amplitude), the time of the downstream part of the rheogram and the average speed of fast and slow blood flow are significantly higher, while the time of the rising part of the rheogram and fast and slow blood overflow and thumb vascular tone rates in most cases are significantly lower. In most cases, 13 and 14-year-old boys, compared to 15 and 16-year-old adolescents, the basic impedance and amplitude of the systolic wave, as well as most vascular tone rates and average slow-blood flow rates are significantly higher or tend to be higher. It has also been found that most of the time indicators (with the exception of slow blood flow time) in 14-year-old boys are significantly lower or tend to be lower than in other age groups of boys. When comparing rheogram data between boys and girls according to the calendar and biological age, the majority of amplitude and derivative indices, as well as the time of slow blood filling in 14 and 15-year-old girls, are significantly higher in girls. Boys have significantly higher values of the duration of the cardiac cycle and the time of the downstream part of the thigh rheogram, as well as all time and most indicators of vascular tone in 13-year-old boys than in 12-year-old girls. Thus, the expressed age and gender differences in the rheogram data of the thigh in practically healthy adolescents have been established.
\end{abstract}

Keywords: thigh rheogram indicators, practically healthy adolescents, age, gender.

\section{Introduction}

The pathology of the vessels of the lower extremities is a rather frequent disease not only among the adult population, but also a significant part of children and adolescents are facing this problem $[13,16,22]$. Genetic predisposition and burdened heredity cause the appearance of this pathology (severe somatic, infectious pathology, smoking, alcohol use and drug addiction in parents, which greatly complicate the process of arteries and veins formation in the fetus) [2, 8, 10, $11,17]$. Violation of the hormonal background in adolescents affects the strength of the vessel wall. With very active growth, the vessels do not keep up with the growth of other body structures. Excessive weight of the child, alcohol and nicotine consumption, low active lifestyle and impaired musculoskeletal system are accompanied by refinement and inhibition in the development of the vessels of the lower extremities [3, 6, 15, 18, 19, 29].

It becomes apparent that varicose veins and other vascular diseases of the leg in adults begin at childhood and adolescence age [7, 24]. A number of cohort studies were conducted that confirmed the following hypothesis: if pathological changes in rheographic indexes were observed in adolescents, this would lead to a pathology 
and complications from the vessels of the lower limbs in adulthood with high probability [1, 11, 32].

In the initial stages and in the stage of compensating the diseases of the vessels of the lower extremities, the adolescent can practically have no complaints and apparent clinical changes may not yet be. Indicators of thigh rheograms from a few functional and instrumental studies are capable of detecting such symptoms that suggest minor changes in blood vessels, do not constitute a critical inconvenience, but already indicating in advance that a more serious illness is approaching [21, 28, 34].

In such conditions, issues related to the definition of risk groups taking into account the age and sex of the subjects are of special importance.

The aim of the study - determine the age and gender features of thigh rheogram indicators in practically healthy adolescents in the Podillia region of Ukraine.

\section{Materials and methods}

On the base of the research center of the National Pirogov Memorial Medical University, Vinnytsya conducted a survey of 103 practically healthy boys aged from 13 to 16 years old and 108 girls aged from 12 to 15 years old, urban residents of the Podillia region of Ukraine. The contingent of practically healthy individuals was formed according to the data of the previous questionnaire and the results of instrumental and clinical-laboratory examinations.

The rheographic parameters of the thigh were determined using a cardiological computer diagnostic complex [36]. The complex provides simultaneous registration of an electrocardiogram, a phonocardiogram, a basic and differential tetrapolar rheogram and a measurement of an arterial pressure. For registration, tape rheovasographic electrodes TE.293.063-01 were used, production of Open Joint Stock Company "NDI REMA" type "roulette" with a width of $6 \mathrm{~mm}$ tape and a distance between the strips $10 \mathrm{~mm}$. The electrodes were superimposed on the edges of the studied sections of the limbs. The rheographic study was conducted in a room with an air temperature of $20-22^{\circ} \mathrm{C}$. The study was conducted in a horizontal position of the person after a 10-15 minute rest on the onset. Prior to registration, the investigated areas in the places of electrode overlay were treated with alcohol, and then with a physiological solution to reduce the resistance of the electrode-skin contact. Also, the electrodes were treated with alcohol before each overlay. Before each measurement, the device performed an automatic calibration with the quality control of the electrode overlay. The measuring current is $1.8 \mathrm{~mA}$, the current is $80 \mathrm{kHz}$. For the analysis $15 \mathrm{~s}$ rheogram records were used, with subsequent program averaging of all periods of oscillation. This allowed increasing the accuracy of the measurements and significantly reducing the impact level of interference on the measurement results. As a result of processing rheograms, the characteristic points on the curve were automatically determined, the main indicators were determined, the conclusion about the condition of the circulatory system of the investigated area was formed.

The statistical processing of the results obtained in the license package "Statistica 5.5" using parametric and nonparametric methods for evaluating the results.

\section{Results}

Among the amplitude indices of thigh rheograms in girls aged from 12 to 15 years, the following changes are typical: significantly higher values, or a tendency towards higher values of the base impedance, amplitudes of systolic, diastolic, and fast blood flow in 12-year-old girls, than in other age groups of adolescent girls; the practical absence of a difference in the magnitude of incisura amplitude in girls of all age groups and most ratios of amplitude indices in 13 and 14-year-old girls compared with the value of these indicators in girls in general (Table 1). In boys founded the following changes in the indicators of thigh rheogram: significantly greater values of the basic impedance in 13 and 14-year-old boys than in the 15 and 16-year-olds, and the tendency toward larger values of the systolic wave amplitude in 13-year-old boys than at 16-year-olds; the practical absence of the difference in the magnitude of most amplitude indices (with the exception of the basic impedance) in boys of different ages compared with the value of these indices in boys in general (see Table 1).

When comparing the amplitude indices of thigh rheograms between girls and boys of the corresponding biological or calendar age, attention is given to significantly higher values in the biological age of practically all indicators in girls (with the exception of the amplitude of rapid blood filling in 14 and 15-year-old girls) and all (with the exception of the amplitude of the fast blood supply) by the calendar year (see Table 1).

Among the time indicators of thigh rheograms in girls between 12 and 15 years of age founded the following changes: significantly lower values of time of the ascending part, fast and slow blood flow in 12-year-old girls than in other groups of adolescent girls; significantly higher values of the time of fast blood filling in 13-year-olds than in 14year-old girls; relatively lower values of time of slow blood filling in 13-year-old than in 15-year-old girls; significantly higher values of the time of the downward part in 12-yearold girls than in 13 and 14-year-olds; there is practically no difference in the duration of the heart cycle in young women of all ages and most of the time indices (with the exception of rising part time) in 14-year-old girls, as compared with the data of girls in general (see Table 1). In boys, attention is drawn to the following changes in the time indicators of hip rheograms: significantly lower cardiac cycle duration in 14year-old boys than in other age groups of adolescents; significantly lower values of the time of the downward part in the 14-year-old boys than in the 15 and 16-year-olds; the values of the rising part are significantly lower in the 16-yearold boys than in the 13 and 15-year-olds, and the tendency towards the higher values of this indicator in 13-year-old 
Hmel L. L., Serebrennikova O. A., Kyrychenko Yu. V., Gnenna V. O.

Table 1. Changes in rheogram Indicators in adolescents of different ages.

\begin{tabular}{|c|c|c|c|c|c|c|c|c|}
\hline \multirow{2}{*}{ Indicators } & \multicolumn{4}{|c|}{ Young women } & \multicolumn{4}{|c|}{ Young men } \\
\hline & 12 & 13 & 14 & 15 & 13 & 14 & 15 & 16 \\
\hline B_Z (Ohm) & $\Delta \uparrow$ & $\downarrow \leftrightarrow$ & $\nabla \leftrightarrow$ & $\nabla \leftrightarrow$ & $\boldsymbol{\Delta} \leftrightarrow$ & $\triangle$ & $\boldsymbol{\nabla} \nabla$ & $\boldsymbol{\nabla} \nabla$ \\
\hline B_H1 (Ohm) & $\Delta$ & $\nabla \leftrightarrow$ & $\nabla \leftrightarrow$ & $\nabla$ & $\uparrow_{\leftrightarrow \uparrow}$ & $\leftrightarrow$ & $\downarrow \leftrightarrow$ & $\downarrow_{\leftrightarrow}$ \\
\hline B_H2 (Ohm) & $\leftrightarrow$ & $\leftrightarrow$ & $\leftrightarrow$ & $\leftrightarrow$ & $\leftrightarrow$ & $\uparrow \leftrightarrow$ & $\downarrow \leftrightarrow$ & $\downarrow \leftrightarrow$ \\
\hline B_H3 (Ohm) & $\Delta$ & $\nabla$ & $\nabla \leftrightarrow$ & $\nabla \leftrightarrow$ & $\uparrow \leftrightarrow$ & $\uparrow \leftrightarrow$ & $\downarrow$ & $\leftrightarrow$ \\
\hline B_H4 (Ohm) & $\Delta \uparrow$ & $\downarrow \leftrightarrow \uparrow$ & $\nabla \downarrow$ & $\nabla \downarrow$ & $\uparrow \leftrightarrow$ & $\leftrightarrow$ & $\leftrightarrow$ & $\downarrow \leftrightarrow$ \\
\hline B_C (s) & $\leftrightarrow$ & $\downarrow \leftrightarrow$ & $\leftrightarrow$ & $\uparrow \leftrightarrow$ & $\Delta \downarrow \leftrightarrow$ & $\nabla$ & $\Delta \uparrow$ & $\Delta \leftrightarrow$ \\
\hline B_A (s) & $\nabla$ & $\Delta$ & $\Delta$ & $\Delta$ & $\Delta \uparrow$ & $\downarrow \leftrightarrow \downarrow$ & $\Delta \leftrightarrow \uparrow$ & $\nabla$ \\
\hline B_B (s) & $\Delta$ & $\boldsymbol{\nabla} \downarrow$ & $\nabla \leftrightarrow$ & $\uparrow \leftrightarrow$ & $\downarrow \leftrightarrow$ & $\nabla$ & $\Delta \uparrow$ & $\boldsymbol{\Delta} \uparrow$ \\
\hline B_A1 (s) & $\nabla$ & $\mathbf{\Delta} \triangle$ & $\Delta \nabla \leftrightarrow$ & $\Delta \leftrightarrow$ & $\Delta$ & $\nabla \leftrightarrow$ & $\uparrow \leftrightarrow$ & $\nabla \downarrow$ \\
\hline B_A2 (s) & $\nabla$ & $\Delta \nabla \leftrightarrow$ & $\Delta \leftrightarrow$ & $\Delta \triangle$ & $\leftrightarrow$ & $\leftrightarrow$ & $\uparrow \leftrightarrow$ & $\downarrow \leftrightarrow$ \\
\hline B_H2H1 (\%) & $\downarrow_{\leftrightarrow}$ & $\leftrightarrow \downarrow$ & $\leftrightarrow \downarrow$ & $\uparrow_{\uparrow}$ & $\nabla$ & $\Delta \uparrow$ & $\downarrow \leftrightarrow$ & $\leftrightarrow$ \\
\hline B_H3H1 (\%) & $\Delta \leftrightarrow$ & $\nabla \downarrow \downarrow$ & $\uparrow \leftrightarrow$ & $\uparrow_{\leftrightarrow}$ & $\leftrightarrow$ & $\uparrow \leftrightarrow$ & $\downarrow$ & $\uparrow \leftrightarrow$ \\
\hline B_H4A1 (Ohm/s) & $\Delta$ & $\nabla$ & $\nabla$ & $\nabla$ & $\leftrightarrow$ & $\leftrightarrow$ & $\leftrightarrow$ & $\leftrightarrow$ \\
\hline B_H1H4A2 (Ohm/s) & $\Delta$ & $\nabla$ & $\nabla$ & $\nabla$ & $\uparrow \leftrightarrow$ & $\Delta \leftrightarrow$ & $\nabla \downarrow$ & $\leftrightarrow$ \\
\hline B_AC (\%) & $\nabla$ & $\Delta$ & $\Delta$ & $\Delta$ & $\Delta \uparrow$ & $\Delta \leftrightarrow$ & $\uparrow_{\leftrightarrow}$ & $\nabla \downarrow$ \\
\hline B_A1C (\%) & $\nabla$ & $\Delta \triangle$ & $\Delta \nabla \leftrightarrow$ & $\Delta \nabla \leftrightarrow$ & $\Delta \uparrow$ & $\Delta \downarrow \leftrightarrow$ & $\downarrow \leftrightarrow \uparrow$ & $\nabla \nabla \downarrow$ \\
\hline B_A2C (\%) & $\nabla$ & $\Delta \leftrightarrow$ & $\Delta$ & $\Delta$ & $\leftrightarrow$ & $\Delta \leftrightarrow$ & $\leftrightarrow$ & $\nabla$ \\
\hline B_A1A2 (\%) & $\bar{\nabla} \uparrow \uparrow$ & $\mathbf{\Delta} \uparrow$ & $\downarrow_{\leftrightarrow}$ & $\nabla \downarrow$ & $\overline{\Delta \uparrow}$ & $\downarrow_{\leftrightarrow}$ & $\leftrightarrow$ & $\nabla \leftrightarrow$ \\
\hline
\end{tabular}

Notes: $\leftrightarrow$ - the value of the indicator within the respective groups of young men or girls does not differ significantly from its size in boys or girls in general; $\uparrow$ or $\downarrow$ - the value of the corresponding indicators within the respective groups of boys or girls has a slight tendency to larger or smaller values; $\uparrow$ or $\downarrow$ - the value of the corresponding indicators within the respective groups of boys or girls tends to be higher or lower values; $\boldsymbol{\Delta} \Delta$ or $\boldsymbol{\nabla} \nabla$ - reliable differences, between the corresponding indicators in the groups of boys or girls; $\square$ significant differences between boys and girls of the corresponding biological age (higher rates are noted); $\square$ - significant differences between boys and girls of the corresponding calendar age (marked higher scores) B_ - rheographic indexes of the thigh; Z - basic impedance;_H1 - amplitude of the systolic wave;_H2 - incisura amplitude; _H3 - amplitude of diastolic wave; _H4 - the amplitude of rapid blood flow; _C - duration of the heart cycle; A - time of the ascending part; _B - time of the downward part; $A$ A1 - time of fast blood filling; _A2 - time of slow blood flow;_H2H1 - dicrotic index; _H3H1 - diastolic index; _H4A1 - average speed fast blood flow rate; _H1 H4A2 - the average speed of slow blood flow; AC - index of tone of all arteries; $A 1 \mathrm{C}$ - index of tone of arteries of large diameter; $A \overline{2} \mathrm{C}$ - index of tone of arteries of medium to small diameter; _A1A2 - ratio of arteries tones.

boys compared with 14-year-olds; significantly higher values of the time of rapid blood filling in 13-year-old boys than in the 14 and 16-year-olds; the practical absence of a difference in the amount of time of slow blood flow in boys of different ages compared with the value of this indicator in boys in general (see Table 1).

When comparing the time indicators of thigh rheograms between girls and boys of the corresponding biological or calendar age, the values of the following indicators are significantly higher: the time of the downward part of the 15year-old girls than the 16-year-old boys; the time of slow blood filling in 14 and 15-year-old girls than in the corresponding biological and calendar age groups of boys; duration of the heart cycle and time of the downward part in all boys by biological and calendar age groups; time of rising, fast and slow blood filling in 13-year-old boys than in 12year-old girls and time of rapid blood filling in 13-year-old boys than in 13-year-old girls (see Table 1).
Among the derivatives of thigh rheogram in girls from 12 to 15 years characterized the following changes: significantly higher indicators of mean average speed of fast and slow blood flow in 12-year-old girls than in other age groups of adolescent girls; the value of the diastolic index in 13-yearold girls is significantly lower than in the 12-year-olds and the tendency towards smaller values compared to 15-yearold girls; the values of the indicators of tone of all arteries, the tone of arteries of large diameter and the tone of middle and small diameter arteries in 12-year-old girls are significantly lower than that of other age groups of adolescent girls and significantly higher values of the indicator of highdiameter arteries in 13-year-old girls than in 14 and 15 years old; the value of the ratio of arterial tone in 13-year-old girls is significantly higher than in the 12 and 15-year-olds, and the tendency towards higher values compared to 14-yearold girls; the tendency to lower values of the dicrotic index in 12-year-old girls than in the 15-year-olds (see Table 1). In 
boys are found to the following changes in the derivative of the thigh rheogram: the 13-year-old boys have significantly less value of the dicrotic index than the 14-year-old boys; the value of the average rate of slow blood flow in 14-year-old boys is significantly higher than that of 15 -year-old adolescents; the value of the indicator of the tone of all arteries in 16-year-old boys is significantly lower than that of the 13 and 14-year-olds, and the tendency towards smaller values than those of 15-year-olds; the value of the indicator of largediameter arteries in 13-year-old boys is significantly higher than in the 16-year-olds and the tendency towards larger values compared to 14 and 15-year-old adolescents, as well as a significantly higher value of the value of this indicator in 14-year-old boys than in 16 years old; the value of the indicator of average and small diameter arteries in the 14-year-old boys is significantly higher than that of the 16-year-olds; the value of the indicator of the arterial tone ratio in 13-year-old boys is significantly higher than in the 16-year-olds and the tendency towards higher values compared to 14-year-old adolescents; the practical absence of a difference in the magnitude of the majority (with the exception of the dicrotic or diastolic indexes) of the ratio of the amplitude to the time indices in boys 14 and 15 years in comparison with the value of these indices in girls in general (see Table 1).

When comparing the derivatives of the rheogram of the thighs between girls and boys of the corresponding biological or calendar age, the values of the following indicators are significantly higher: the dicrotic index in girls of 14 years old than in boys 15 and in girls 13 and 15 years than in boys of 13 and 15 years; the average speed of rapid blood flow in girls of 12 and 14 years old than in boys of 13 and 15 years old and girls 13-15 years old than in boys of the corresponding calendar age; the average rate of slow blood flow in all groups of girls of the corresponding biological and calendar age; the indicator of the tone of all arteries and the tone of arteries of medium to small diameter in girls 1315 years old than in boys of the corresponding biological and calendar age and the index of tone of all arteries in 13year-old boys than in 12-year-old girls; an indicator of the tone of arteries of large diameter in 13-year-old girls than in 14-year-old boys and 13-year-old boys than in 12-year-old girls; an indicator of the ratio of arterial tone in boys 13 and 15 years, than in girls 12 and 14 years old, and in boys 1315 years old, than in girls of the corresponding calendar year (see Table 1).

\section{Discussion}

In recent years, attention has been paid to the study of morphofunctional changes in the arterial and venous vessels of the lower extremities during human ontogenesis [4, 9]. In the process of growth and development of the child's body, there are structural and functional alterations in the vessels, which manifest themselves in a natural change in vascular tone and mechanisms for its regulation. The tone of the limb vessels in healthy children from 10 to 17 years undergoes changes related to maturation of the mechanisms of vegetative regulation. With age, the central regulatory influence of the autonomic nervous system decreases and the activity of autonomous contour of vegetative regulation increases due to the predominance of parasympathetic influences. This leads to a reduction in the blood supply intensity of the unit volume of tissue and an increase in the tone of the vessels of the extremities of large and medium diameters [9, 14].

The tone and the magnitude of the propulsive activity of vessels in both sexes are significantly different. In boys, compared with girls, higher volumetric blood flow rates and specific peripheral vascular resistance is found; lower tone of arterioles, but higher tone of veins, with the following explanation. In the males diameters of the major vessels of the lower extremities dominate in the upper and middle third of the thigh $[5,33]$. The activity of the sympathoadrenal system and vasotropic effects are controlled by sex hormones (the expansion of peripheral vessels in the female is due to the effect of estrogen) [20, 23, 27].

In a number of studies $[5,12,25,26,35]$ for children and adults had established age and gender differences in rheogram indices of the lower extremities. The teenage age in this direction remains virtually uninvestigated.

When analyzing the age and sexual characteristics of the thigh rheogram in practically healthy teens, we have established the following changes:

- age features of thigh rheogram indicators in young women: 1) in 12-year-old girls, most of the amplitude indices (with the exception of the incisura amplitude) are significantly higher than in other age groups of girls; 2) the time of the ascending part of the rheogram and fast and slow blood supply is significantly lower, and the time of the downward part of the rheogram is in most cases significantly higher in 12-year-old girls than in other age groups; 3) the average speed of fast and slow blood filling in 12-year-old girls is significantly higher, and vascular tones in most cases are significantly lower than in other age groups of girls;

- age characteristics of thigh rheogram indicators in boys: 1) only the basic impedance and amplitude of the systolic wave are in most cases significantly higher, or tend to be higher in 13 and 14-year-old boys than in 15 and 16-yearolds; 2 ) most of the time indicators (except for the time of slow blood flow) in 14-year-old boys are significantly lower or tend to be lower than those of other age groups of boys; 3 ) in 13 and 14-year-old boys, most vascular tones indicators and the average slow-blood flow rate are significantly higher or tend to be higher than those of 15 and 16-year-old boys;

- sexual characteristics of indicators of rheograms of the thigh in adolescents: 1) most of the amplitude rheogram parameters of the thigh are significantly higher in girls, both in the calendar and in the biological age; 2) among the time indicators, the duration of the cardiac cycle and the time of the downward part of the thigh rheogram are significantly higher than the calendar and biological age of the boys; the attention is drawn to the fact that all time indicators in 13-year-old boys are significantly higher than those of 12-year-old girls and 
significantly higher values of slow blood flow in 14 and 15year-old girls, both in calendar and in biological age; 3 ) in most cases, among the derivatives of the rheogram of the thighs significantly higher values have girls; only the majority of indicators of vascular tone in 13-year-old boys are significantly higher than in 12-year-old girls.

In the study of the indicators of thigh rheovasograms in practically healthy young men and women, Vadzuk S. N. and Tsvyntarnyi A. V. [30, 31] found that 20-year-old young women, compared with young women 16-19 years old, have higher blood-flow rates of arteries of large, medium and small caliber, a tone of arteries of large caliber, but lower tone indices of all arteries and arteries of medium and small caliber. In young men, a smaller number of age differences in the parameters of the thigh rheogram is established only smaller values of the indicator of the tone of the arteries of middle and small caliber at 20-year-olds than those of 18 and 19-year-old young men. In the analysis of gender differences in the rheogram of the thigh, the authors, as in our studies, found that girls of the general group and all age groups were larger than the corresponding groups of boys, the values of all amplitude and derivative indices of the rheogram, as well as the time of slow blood filling.

The obtained results broaden the idea of the peculiarities of the activity of the vessels of the lower extremities in healthy teens, depending on gender and age, which will allow, substantiated and differentiated normalize muscle loading

\section{References}

[1] Ahti, T. M., Makivaara, L. A., Luukkaala, T., Hakama, M., \& Laurikka, J. O. (2009). Effect of family history on the incidence of varicose veins: a population-based follow-up study in Finland. Angiology, 60(4), 487-491. doi: 10.1177/ 0003319709335510

[2] Antle, D. M., Cormier, L., Findlay, M., Miller, L. L., \& Cote, J. N. (2018). Lower limb blood flow and mean arterial pressure during standing and seated work: Implications for workplace posture recommendations. Prev. Med. Rep., 10, 117-122. doi: https://doi.org/10.1016/j.pmedr.2018.02.016

[3] Antle, D. M., Vezina, N., \& Cote, J. N. (2015). Comparing standing posture and use of a sit-stand stool: analysis of vascular, muscular and discomfort outcomes during simulated industrial work. Int. J. Ind. Ergon., 45, 98-106. doi: https://doi.org/10.1016/ j.ergon.2014.12.009

[4] Apikina, T. A., Zefirov, T. L.., Rusinova, S. I., Sitdikov, F. G., Bilalova, G. A., Dikopolskaya, N. B., ... Zverev, A. A. (2013). Age anatomy, physiology and hygiene: a training manual. Kazan, KFU.

[5] Azhim, A., Akioka, K., Akutagawa, M., Hirao, Y., Yoshizaki, K., Obara, S., ... Kinouchi, Y. (2007). Effect of gender on blood flow velocities and blood pressure: role of body weight and height. Conf. Proc. IEEE Eng. Med. Biol. Soc., 2007, 967-970. doi: 10.1109/IEMBS.2007.4352453

[6] Breitling, L. P. (2013). Current genetics and epigenetics of smoking/tobacco-related cardiovascular disease. Arterioscler. Thromb. Vasc. Biol., 33(7), 1468-1472. doi: 10.1161/ATVBAHA. 112.300157

[7] Buryak, V. N, \& Mahmutov, V. N. (2011). Features of vascular tone in children with arterial hypotension. Modern Pediatrics, 1, 89-91. in the process of their physical education. This will contribute to the correct development of the organism, increase its functional and reserve capacity for various environmental influences. The results of the research will be able to find practical application in age and sports physiology, in pediatrics, in preventive medicine and angiology.

\section{Conclusions}

1. 12-year-old girls have significantly higher values than girls of other age groups (with the exception of the incisura amplitude), the time of the downstream part of the rheogram, the average speed of fast and slow blood flow, and significantly lower values of the time of the rising part of the rheogram and fast and slow blood flow, as well as vascular tone.

2. 13 and 14-year-old boys have significantly higher or tended to higher values than the 15 and 16-year baseline impedance and amplitude of the systolic wave, most vascular tone indices, and the average slow-blood flow speed, and only in 14-year-old boys - significantly lower, or a tendency towards lower values of most time indices (with the exception of the time of slow blood transfusion).

3. Established manifestations of sexual dimorphism of thigh rheogram indicators in adolescence: most of the amplitude and derivative indices are significantly higher in girls, and the duration of the cardiac cycle and the time of the downward part are significantly higher in boys.

[8] Chang, P. N. K., Olin, J. W., Cooke, J. P., \& Leeper, N. J. (2014). Clinical and socioeconomic factors associated with unrecognized peripheral artery disease. Vasc. Med., 19(4), 289-296. doi: 10.1177/1358863X14535475

[9] Dilenyan, L. P., Bagriy, A. S., Dilenyan, L. P., Belkaniya, G. S., Bagriy, A. S., Korepanov, S. K., ... Puhalskaya, L. G. (2015). Anthropophysiological characteristics of the "hemodynamic model" of the age dynamics of blood circulation in humans. Modern problems of science and education, 2(2), 26-34.

[10] Fiebig, A., Krusche, P., Wolf, A., Krawczak, M., Timm, B., Nikolaus, S., ... Schreiber, S. (2010). Heritability of chronic venous disease. Hum. Genet., 127(6), 669-674. doi: 10.1007/ s00439-010-0812-9

[11] Fowkes, F. G., Rudan, D., Rudan, I., Aboyans, V., Denenberg, J. O., McDermott, M. M., ... Criqui, M. H. (2013). Comparison of global estimates of prevalence and risk factors for peripheral artery disease in 2000 and 2010: a systematic review and analysis. Lancet, 382, 1329-1340. doi: https://doi.org/10.1016/ S0140-6736(13)61249-0

[12] Fronek, A., Criqui, M. H., Denenberg, J., \& Langer, R. D. (2001). Common femoral vein dimensions and hemodynamics including Valsalva response as a function of sex, age, and ethnicity in a population study. Journal of vascular surgery, 33(5), 10501056. doi: $10.1067 / m v a .2001 .113496$

[13] Hirsch, A. T., Hartman, L., Town, R. J., \& Virnig, B. A. (2008). National health care costs of peripheral arterial disease in the Medicare population. Vasc. Med., 13(3), 209-215. doi: 10.1177/ $1358863 \times 08089277$

[14] Kapilevich, L. V., Kabachkova, A. V., \& Dyakova, E. Yu. (2009). Age morphology: Tutorial. Tomsk: Tomsk State University.

[15] Karol, S., \& Robertson, M. M. (2015). Implications of sit-stand 
and active workstations to counteract the adverse effects of sedentary work: a comprehensive review. Work, 52(2), 255267. doi: 10.3233/WOR-152168

[16] Komarova, L. N., Ryakhin, R. N., Aliev, F. S., \& Zvezda, S. A. (2018). Ten-year results of varicose veins treatment. The Russian Archives of Internal Medicine, 3, 215-218.

[17] Kullo, I. J., \& Leeper, N. J. (2015). The Genetic Basis of Peripheral Arterial Disease: Current Knowledge, Challenges and Future Directions. Circ. Res., 116(9), 1551-1560. doi: 10.1161/ CIRCRESAHA. 116.303518

[18] Leeper, N. J., Kullo, I. J., \& Cooke, J. P. (2012). Genetics of peripheral artery disease. Circulation, 125(25), 3220-3228. doi: 10.1161/CIRCULATIONAHA. 111.033878

[19] Lu, J. T., \& Creager, M. A. (2004). The Relationship of Cigarette Smoking to Peripheral Arterial Disease. Reviews in cardiovascular medicine, 5(4), 189-193. PMID: 15580157

[20] Matouk, C. C., \& Marsden, P. A. (2008). Epigenetic regulation of vascular endothelial gene expression. Circ. Res., 102(8), 873887. doi: 10.1161/CIRCRESAHA.107.171025

[21] Messing, K., Tissot, F., \& Stock, S. R. (2008). Distal lowerextremity pain and work postures in the Quebec population. Am. J. Public. Health., 98(4), 705-713. doi: 10.2105/ AJPH.2006.099317

[22] Nicolaides, A. N., Kakkos, S., Baekgaard, N., Comerota, A., de Maeseneer, M., Eklof, B., ... Perrin, M. (2018). Management of chronic venous disorders of the lower limbs. Guidelines according to scientific evidence. Part I. Int. Angiol., 37(3), 181-254. doi: 10.23736/S0392-9590.18.03999-8

[23] Olson, T. P., Schmitz, K. H., Leon, A. S., \& Dengel, D. R. (2006). Vascular structure and function in women: relationship with body mass index. American journal of preventive medicine, 30(6), 487-492. doi: 10.1016/j.amepre.2006.02.006

[24] Ovcharenko, D. V., Kaputin, M. Yu. Voronkov A. A., \& Platonov, S. A. (2012). Angiographic study of the anatomical variability of the arteries of the shin and foot. Angiology and Vascular Surgery, 18(1), 57-60.

[25] Proctor, D. N., Le, K. U., \& Ridout, S. J. (2005). Age and regional specificity of peak limb vascular conductance in men. Journal of Applied Physiology, 98(1), 193-202. doi: 10.1152/ japplphysiol.00704.2004

[26] Ridout, S. J., Parker, B. A., \& Proctor, D. N. (2005). Age and regional specificity of peak limb vascular conductance in women. Journal of Applied Physiology, 99(6), 2067-2074. doi: 10.1152/japplphysiol.00825.2005

[27] Sandoo, A., Veldhuijzen van Zanten, J. J. C. S., Metsios, G. S., Carroll, D., \& Kitas, G. D. (2010). The Endothelium and Its Role in Regulating Vascular Tone. Open Cardiovasc Med. J., 4, 302-312. doi: 10.2174/1874192401004010302

[28] Shvalb, P. G., \& Uhov, Yu. I. (2009). Pathology of venous return from the lower extremities. Ryazan: "Tigel".

[29] Tabatabaeifar, S., Frost, P., Andersen, J. H., Jensen, L. D., Thomsen, J. F., \& Svendsen, S. W. (2015). Varicose veins in the lower extremities in relation to occupational mechanical exposures: a longitudinal study. Occup. Environ. Med., 72(5), 330-337. doi: 10.1136/oemed-2014-102495

[30] Tsvyntarnyi, A. V., \& Vadzuk, S. N. (2014). Features of the derivative indices of the rheogram of the thigh in healthy young men and girls of all ages. Bulletin of scientific research, 1(74), 37-39.

[31] Vadzuk, S. N., \& Tsvyntarnyi, A. V. (2015). Age features of time and amplitude rheogram data of the thigh in healthy urban boys and girls. Bulletin of scientific research, 1(78), 20-22.

[32] Valdez, R., Yoon, P. W., Qureshi, N., Green, R. F., \& Khoury, M. J. (2010). Family History in Public Health Practice: A Genomic Tool for Disease Prevention and Health Promotion. Ann. Rev. of Publ. Health., 31, 69-87. doi: 10.1146/ annurev.publhealth.012809.103621

[33] Vebyakova, N. A., Fadeeva, N. A., \& Feliksova, O. M. (2013). Gender features of hemodynamic reactions to loading. Basic research, 5(1), 33-37.

[34] Vereskun, Z. F., \& Vereskun, S. B. (2011). The place of rheography in the clinical diagnosis of vascular pathology. New medicine of the millennium, 1, 56-58.

[35] Vysochanskyi, O. V. (2015). Sexual peculiarities of the relationships of indices of rheovasogram with anthroposomatotypological parameters in healthy teens of mesomorphic somatotype. Abstracts are presented in the materials of the international scientific and practical conference "Medical science and practice: topical issues of interaction", (Kyiv, pp. 60-63). Kyiv: Kiev Medical Scientific Center.

[36] Zelinsky, B. O., Zlepko, S. M., Kostenko, M. P., \& Kovalchuk, B. M. (2000). Portable multifunctional device for diagnosing the vascular bed of the circulatory system. Measuring and computing engineering in technological processes, 1, 125-132.

\section{ВІКОВІ ТА СТАТЕВІ ОСОБЛИВОСТІ ПОКАЗНИКІВ РЕОГРАМИ СТЕГНА У ПРАКТИЧНО ЗДОРОВИХ ПІДЛІТКІВ Хмель Л. Л., Серебреннікова О. А., Кириченко Ю. В., Гненна В. О.}

Зәідно даних багатьох досліджень реовазографічні показники стегна здатні виявити незначні зміни судин, що не становлять собою критичних незручностей, але заздалегідь свідчать про наближення більш серйозних захворювань нижньої кінцівки. Мета дослідження - встановити вікові та статеві особливості показників реограми стегна у практично здорових підлітків Подільського регіону України. Реографічні параметри стегна 103 практично здорових хлопчиків віком від 13 до 16 років та 108 дівчаток віком від 12 до 15 років, міських мешканців Подільського регіону України, визначали за допомогою кардіологічного комп'ютерного діагностичного комплексу. Статистична обробка отриманих результатів проведена в ліцензійному пакеті "Statistica 5.5" з використанням параметричних і непараметричних методів оцінки отриманих результатів. У 12-річних дівчаток, у порівнянні з іншими віковими групами, встановлено, що більшість амплітудних показників (за винятком амплітуди інцізури), час низхідної частини реограми та середня швидкість швидкого і повільного кровонаповнення достовірно більші, а час висхідної частини реограми та швидкого і повільного кровонаповнення та показники тонусу судин стегна у більшості випадків достовірно менші. У більшості випадків у 13 і 14-річних хлопчиків, у порівнянні з 15 і 16-річними підлітками, базовий імпеданс і амплітуда систолічної хвилі, а також більшість показників тонусу судин та середня швидкість повільного кровонаповнення достовірно більші, або мають тенденцію до більших значень. Також встановлено, що більшість часових показників (за винятком часу повільного кровонаповнення) у 14-річних хлопчиків достовірно менші, або мають тенденцію до менших значень, ніж у хлопчиків інших вікових груп. При порівнянні показників реограми стегна між хлопчиками та дівчатками за календарним і за біологічним віком встановлено достовірно більші значення у дівчаток більшості амплітудних і похідних показників, а також часу повільного кровонаповнення у 14 і 15-річних дівчаток. У хлопчиків встановлені достовірно більші значення тривалості серцевого циклу та часу низхідної частини реограми стегна, а також усіх часових показників $і$ 
більшості показників тонусу судин у 13-річних хлопчиків, ніж у 12-річних дівчаток. Таким чином встановлені виражені вікові та статеві відмінності показників реограми стегна у практично здорових підлітків.

Ключові слова: показники реограми стегна, практично здорові підлітки, вік, стать.

\section{ВОЗРАСТНЫЕ И ПОЛОВЫЕ ОСОБЕННОСТИ ПОКАЗАТЕЛЕЙ РЕОГРАММЫ БЕДРА У ПРАКТИЧЕСКИ ЗДОРОВЫХ ПОДРОСТКОВ \\ Хмель Л. Л., Серебренникова О. А., Кириченко Ю. В., Гненная В. О.}

Согласно данным многих исследований реовазографические показатели бедра способны выявить незначительные изменения сосудов, не представляющих собой критических неудобств, но заранее свидетельствуют о приближении более серьезных заболеваний нижней конечности. Цель исследования - установить возрастные и половые особенности показателей реограммы бедра у практически здоровых подростков Подольского региона Украины. Реографические параметры бедра 103 практически здоровых мальчиков в возрасте от 13 до 16 лет и 108 девочек в возрасте от 12 до 15 лет, городских жителей Подольского региона Украины, определяли с помощью кардиологического компьютерного диагностического комплекса. Статистическая обработка полученных результатов проведена в лицензионном пакете "Statistica 5.5" c использованием параметрических и непараметрических методов оченки полученных результатов. У 12-летних девочек, в сравнении с другими возрастными группами, установлено, что большинство амплитудных показателей (за исключением амплитуды инцизуры), время нисходящей части реограммы и средняя скорость быстрого и медленного кровенаполнения достоверно больше, а время восходящей части реограммы и быстрого и медленного кровенаполнения и показатели тонуса сосудов бедра в большинстве случаев достоверно меньше. В большинстве случаев у 13 и 14-летних мальчиков, по сравнению с 15 и 16-летними подростками, базовый импеданс и амплитуда систолической волны, а также большинство показателей тонуса сосудов и средняя скорость медленного кровенаполнения достоверно больще, или имеют тенденцию к большим значениям. Также установлено, что большинство временных показателей (за исключением времени медленного кровенаполнения) у 14-летних мальчиков достоверно меньше, или имеют тенденцию к меньшим значениям, чем у других возрастных групп мальчиков. При сравнении показателей реограммы бедра между мальчиками и девочками по календарному и по биологическому возрасту установлено достоверно большие значения у девочек большинства амплитудных и производных показателей, а также времени медленного кровенаполнения у 14 и 15-летних девочек. У мальчиков установлены достоверно большие значения продолжительности сердечного цикла и времени нисходящей части реограммы бедра, а также всех временных показателей и большинства показателей тонуса сосудов у 13-летних мальчиков, чем у 12-летних девочек. Таким образом установлены выраженные возрастные и половые различия показателей реограммы бедра у практически здоровых подростков.

Ключевые слова: показатели реограммы бедра, практически здоровые подростки, возраст, пол. 